\title{
Adiwiyata (Green School) Program Optimization Strategy in Malang Regency to Realize Environmentally Friendly School Citizens
}

\author{
Hana Naqiyya Nada1 ${ }^{*}$, Rhina Uchyani Fajarningsih ${ }^{2}$, Okid Parama Astirin ${ }^{3}$ \\ 1,2,3Universitas Sebelas Maret, Surakarta, Indonesia
}

\begin{tabular}{|c|c|}
\hline A) Check for updates open access CC) (1) (2) & DOI : https://doi.org/10.46245/ijorer.v2i2.83 \\
\hline Sections Info & ABSTRACT \\
\hline Article history: & Globalization encourages rampant development by exploiting natural \\
\hline Submitted: December 30, 2020 & resources on a large scale. Adiwiyata program is a manifestation of \\
\hline Final Revised: January 29, 2021 & environmental education to raise awareness and concern about the \\
\hline Accepted: January 30, 2020 & environment. However, the number of Adiwiyata schools is still small, and \\
\hline Published Online: March 31, 2021 & its implementation has met challenges and obstacles. The research aims to \\
\hline Keywords: & formulate a development strategy for the Adiwiyata program to run \\
\hline Adiwiyata & optimally and achieve the goals. The research was conducted in Adiwiyata \\
\hline Environmental learning & elementary school, junior high, and high school level in Malang regency \\
\hline Green School & consisting of Adiwiyata Award school (National or Independent) and \\
\hline Strategy & Adiwiyata non-Award (District or Province).The study used a qualitative \\
\hline SWOT & descriptive method with IFAS and EFAS matrices, and then a SWOT and \\
\hline 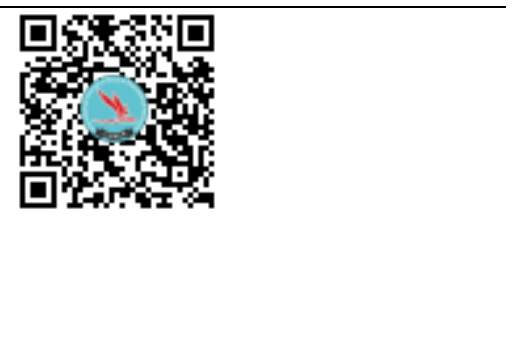 & $\begin{array}{l}\text { QSPM analysis was performed. The results revealed that Adiwiyata program } \\
\text { implementation in Malang Regency was carried out quite well. Several } \\
\text { supporting factors and obstacles came from inside and outside the school. } \\
\text { The planning and growth strategies were formulated for the Adiwiyata non- } \\
\text { awarded schools in quadrant II }(2.24 ;-0.08) \text {, while the rewarded Adiwiyata } \\
\text { schools were in quadrant I }(2.35 ; 2.88) \text { with alternative development and } \\
\text { sustainability strategies. The strategy formulation results are expected to be } \\
\text { used as a reference in the development of the Adiwiyata program in Malang } \\
\text { Regency. }\end{array}$ \\
\hline
\end{tabular}

\section{INTRODUCTION}

The progress of science and technology is overgrowing. This progress is influenced by globalization development, making it easy to disseminate information and improve the economy, but it impacts one's behavior (Ergashev and Farxodjonova, 2020). The fastpaced and practical life pattern encourages humans to utilize technology consumptively for natural resources. Intensive development is carried out by exploiting natural resources to meet needs. The lack of environmental awareness and concern in the development process will affect the balance of environmental carrying capacity and environmental capacity until it ends in environmental damage (Pramanik et al., 2018).

Awareness and concern will grow based on education. Education is a very significant main factor in influencing ecologically conscious behavior (Setyanto, 2018). Eighteen characters should be developed in the education process according to the Ministry of Education, including religion, honesty, tolerance for diversity, discipline, hardworking, creativity, free, democratic, curiosity, the spirit of nationalism, love for the country, achievement, friendly/communicative, love peace, love to read, care about the environment, care about socially, and be responsible (Fahmy et al., 2015).

Environmental education at Adiwiyata school (green school) is an effort to implement character education by promoting exemplary and habituation (Rokhman et al., 2013). According to Iswari and Utomo (2017), the Adiwiyata program is a manifestation of environmental education that can expand student knowledge and shape attitudes and 
Adiwiyata (Green School) Program Optimization Strategy in Malang Regency to Realize Environmentally Friendly School Citizens

actions towards the environment. Good behavior will be easily managed through competence, desire, and behavior habits (Pane \& Patriana, 2016). Therefore, the Adiwiyata program is very influential on students' care for the environment through the Caring and Cultured School Environment Movement (PBLHS Movement).

Adiwiyata School has four levels, namely Adiwiyata Regency/ City, Province, National, and Independent. The National and Independent Adiwiyata School is an award-winning Adiwiyata School where it serves as a referral school that affects the Adiwiyata program to other schools. Adiwiyata Regency/City School is an impact school that is fostered by the award-awarded Adiwiyata School. The two schools are closely related and need each other. Adiwiyata Schools are participatory from referral schools, impact schools, governments, and local communities to play an active and highly motivated role in solving environmental problems (Tompodung et al., 2018). Active participation from all parties will build responsibility and commitment to implement the program that has been planned together (Bandiyah, 2016). Referral schools play a role in fostering impact schools with systematic and organized planning and regular mentoring and evaluation. In contrast, impact schools are required to participate actively, be responsible, and be committed to running the program (Sulistyowati et al., 2017).

Adiwiyata school brings a good impact on education, where the intensity of student involvement in environmental activities will affect personality, form responsible behavior, and have good management perspectives and abilities (Pratiwi et al., 2019). Adiwiyata program has various benefits for environmental preservation, but in its implementation, it encountered some difficulties. The Adiwiyata school development in Malang Regency, for example, was relatively low. Environmental Agency's data for Malang Regency showed that only $6 \%$ of the total number of Malang Regency schools had participated in the Adiwiyata program.

Representatives of the Environmental Agency Malang Regency stated that the socialization and evaluation were still lacking. Some schools were reluctant to participate in the Adiwiyata program because they considered it a costly and complicated competition in terms of administration. The vast area of the Malang Regency also became an obstacle in the monitoring and evaluation process so that the program has run less optimally. Strategies are needed to achieve goals, optimize the program's results, and respond to strengths, weaknesses, opportunities, and threats (Aldi, 2015). Based on this background, research is needed to formulate an optimization strategy for the Adiwiyata program in Malang Regency to run optimally and provide better results.

\section{RESEARCH METHOD \\ General Background}

The research design used descriptive qualitative to elucidate in detail the Adiwiyata program in Malang Regency. This method was chosen to describe events or phenomena through whom, what, where, how, and why these events could occur in detail and comprehensively (Bradshaw et al., 2017). The IFAS and EFAS matrices are used to identify internal and external factors. This factor is then used to explore the strengths and opportunities that can be maximized in minimizing weaknesses and threats (Banihashemi and Rejaei, 2016). This research aimed to formulate a strategy based on 
Adiwiyata (Green School) Program Optimization Strategy in Malang Regency to Realize Environmentally Friendly School Citizens

internal and external conditions for the Adiwiyata program development in Malang Regency.

\section{Sample and Participants}

The data were obtained from six Adiwiyata schools, consisting of two elementary schools, two junior high schools, and two senior high schools. Each category consisted of rewarded Adiwiyata schools (National/Independent) and non-awarded (District/Province). Respondents who have taken to determine the strategy formulation's weight and rating were one person who understood the Adiwiyata program in the school and one representative from the Malang Regency Environmental Service. The list of Adiwiyata schools that participated in this study is shown in Table 1.

Table. 1 List of research location.

\begin{tabular}{ccc}
\hline Grade & $\begin{array}{c}\text { Rewarded Adiwiyata schools } \\
\text { (National/Independent) }\end{array}$ & $\begin{array}{c}\text { Non-awarded Adiwiyata schools } \\
\text { (District/Province) }\end{array}$ \\
\hline $\begin{array}{c}\text { Elementary } \\
\text { School }\end{array}$ & $\begin{array}{c}\text { State Elementary School 04 } \\
\text { Panggungrejo }\end{array}$ & Elementary School 03 Turen \\
\hline $\begin{array}{c}\text { Junior High } \\
\text { School }\end{array}$ & State Junior High School 1 Wajak & $\begin{array}{c}\text { State Junior High School 1 } \\
\text { Gondanglegi }\end{array}$ \\
\hline $\begin{array}{c}\text { Senior High } \\
\text { School }\end{array}$ & State Senior High School 1 Kepanjen & $\begin{array}{c}\text { Islamic Senior High School 1 } \\
\text { Gondanglegi }\end{array}$ \\
\hline
\end{tabular}

\section{Instrument and Procedures}

The data collection utilized in-depth interviews, thorough observation, and documentation.

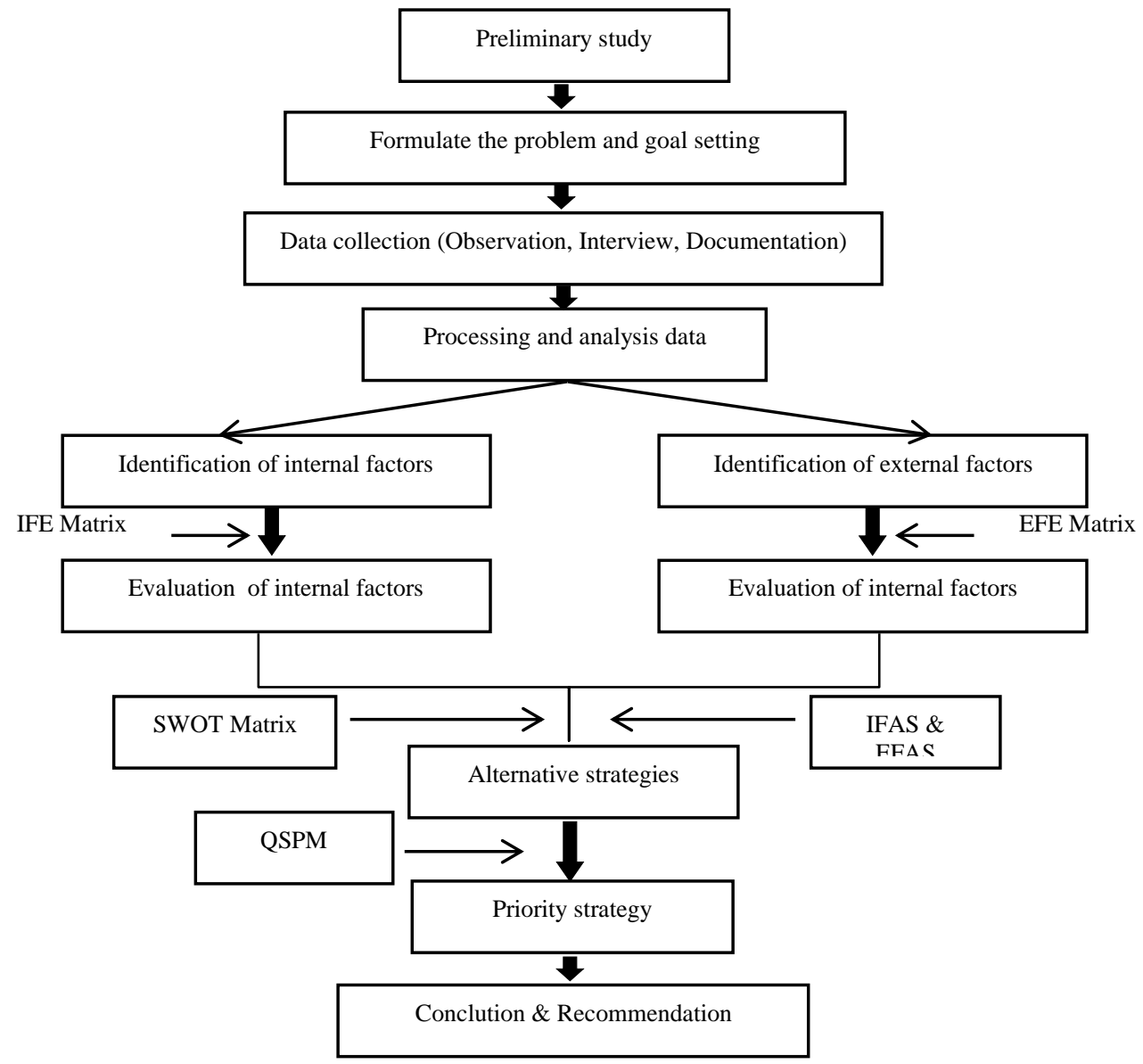


Adiwiyata (Green School) Program Optimization Strategy in Malang Regency to Realize Environmentally Friendly School Citizens

Figure 1. Research procedure flowchart (Modified from Yogi et al., 2017).

The instruments used were interview sheets, observation sheets, voice recording devices, and cameras. Before use, instruments are tested for validity and reliability first. The validity of the instrument is tested through in-depth interviews with experts (logical validity) and also the first review with informants (face validity) (Hendryadi, 2017). Before the data is presented, first discuss researchers and informants so that understanding and data found is not in doubt its validity. Data reliability is attempted by making operational research steps by preparing research evidence data that can be used as re-verification and a detailed description of the research results (Nugrahani \& Hum, 2014). The procedures employed to obtain the right strategy included (1) identifying internal and external factors, (2) analyzing internal and external factor matrices, (3) analyzing Internal Strategic Factors Analysis Summary (IFAS) and External Strategic Factors Analysis Summary (EFAS), and finally (4) decision making using QSPM (David \& David, 2016).

\section{Data Analysis}

This research was qualitative research that used a data analysis method with three stages: data reduction, data display, and conclusion drawing (Miles et al., 2014). Strategy determination employed IFAS and EFAS matrix analysis, followed by SWOT analysis (Strength, Weakness, Threat, Opportunity) to find alternative strategies, then QSPM (Quantitative Strategic Planning Matrix) was utilized for strategy determination. SWOT and QSPM analysis can determine supporting factors to achieve goals and inhibiting factors that allow them to be minimized to achieve optimal results (Pazouki, Jozi, \& Ziari, 2017).

\section{RESULTS AND DISCUSSION}

Based on the results of interviews, observations, and documentation at six Adiwiyata schools, the following results were obtained:

\section{Adiwiyata Program Implementation in Malang Regency}

The results showed that adiwiyata program is implemented in several aspects contained in environmental care activities. Adiwiyata schools have integrated ecofriendly behavior in daily activities, such as maintaining environmental cleanliness, managing waste, maintaining plants, conserving resources such as water and electricity, and making innovative works. In his study, SDN 03 Turen utilized plastic waste by creating hanging decorations and plant pots used as decorations to beautify the bathroom area. Meanwhile, MAN 1 Gondanglegi utilized packaging bottle waste used as a decoration for gates and plant pots.

The community around the Adiwiyata school has also been affected by environmental activities carried out at the school. The school invited local residents to participate in environmental management. Activities carried out included holding village clean-up competitions, reforestation, or socialization of waste management. Representatives of the Environmental Agency Malang Regency stated that the Adiwiyata program aims to develop not only schools but also become Adiwiyata villages. This program also received support from several agencies, for example, the State University of Malang, which helped build Adiwiyata school and brought an impacted program for the surrounding community 
Adiwiyata (Green School) Program Optimization Strategy in Malang Regency to Realize Environmentally Friendly School Citizens

Adiwiyata schools have collaborated with several supporting agencies. The community health center is the most crucial government agency for health in collaboration with schools. Schools are a means for community health centers to socialize healthy lifestyles, such as immunization, giving vitamins, hygiene, or environmental sanitation, and fostering healthy food. In this study, SMPN 1 Wajak had a healthy canteen awarded the food safety star rating from the National Food and Drug Agency. It was also due to the community health center's role, which participated in providing training on making healthy food from the ingredients used, the manufacturing process, to the nutritional content.

Adiwiyata schools have utilized social media as a means of publicizing environmental activities. For example, SMPN 1 Wajak had a YouTube channel that published school residents' activities in hydroponic maintenance and composting. Meanwhile, SMAN 1 Kepanjen had a website about the entire Adiwiyata program of all POKJA (working groups) starting from schedules, lists of committees or participants, types of activities, and activity documentation reports. Other schools also shared environmental conservation activities through social media, such as Instagram, Facebook, or school websites. Some posters were also displayed in every classroom, wall magazines, and school corners.

Adiwiyata school members were trained to become Adiwiyata cadres. Adiwiyata cadres are expected to be able to spread the Adiwiyata program more widely. Adiwiyata cadres are not only active in school activities but also participate in activities outside of school. The 3rd Garbage Jamboree held by the Malang Regency Government on February 2829, 2020, at TPA Talang Agung was one place for Adiwiyata cadres to know more about waste. This activity contained coaching and an invitation to care about waste management. This activity was also used to exchange information, experiences, and cooperation between schools.

Adiwiyata School predicate is given to schools that have implemented the Environmental Care and Culture Movement in schools hereinafter called the PBLHS Movement. Adiwiyata school assessment includes planning, implementation, and evaluation/monitoring of the PBLHS movement. The results of the research outlined above following the Regulation of the Minister of Environment and Forestry No. 52 of 2019 on the Implementation of the PBLHS Movement include:

* Integration of environmentally friendly behaviors in learning, extracurricular, and habituation in daily activities.

* Application of environmentally friendly behavior for communities around schools or in certain areas.

* Forming networks of work and communication.

* Campaigns and publications of the PBLHS movement.

* Forming and empowering Adiwiyata cadres.

Research by Landriany (2014) shows adiwiyata program has not fully achieved its goal. The lack of participation and enthusiasm of school residents is the main factor hampering the program's implementation. This is in line with the study's findings that school residents' participation is still lacking, tending to depend on certain moments so that it requires innovations and activities that can awaken the spirit and interest of the school residents. 
Adiwiyata (Green School) Program Optimization Strategy in Malang Regency to Realize Environmentally Friendly School Citizens

The Adiwiyata program is voluntary, so that only a few schools are willing to participate in the program. Therefore, this program relies heavily on school residents' participation to be consistent and responsible in implementing the program (Iswari \& Utomo, 2017). Comprehensive integration through both theory and practice is strengthened by policies as guidelines and references in running the Adiwiyata program (Isnaeni, 2014). The change of headmaster is the main factor that inhibits the sustainability of the adiwiyata program. The headmaster is in complete control of the policy and sustainability of the program.

Implementing the adiwiyata program has a positive impact on school residents as awareness of maintaining and caring for the environment can be felt directly (Isnaeni, 2013). The character of environmental care is proven to be approved by implementing good programs through socialization, habituation, and accuracy (Nuzulia et al., 2019). Implementation of the Adiwiyata program supported by all parties' cooperation will improve the quality and quality of education (Pradini et al., 2018).

\section{Supporting factors and obstacles to the Adiwiyata program implementation}

Adiwiyata School provides many benefits so that several factors support the program's running. Still, some difficulties and challenges become inhibitory factors so that the Adiwiyata program has not run optimally. The internal supporting factor (strength) of adiwiyata program obtained from the identification of this research include (a) The existence of Ministerial Regulations for GPBLHS and Adiwiyata, (b) The existence of the Adiwiyata team, (c) Environmental atmosphere, (d) The school community was accustomed to discipline, (e) The awareness of the school community increased, (f) Quality graduates and school members, and (g) Organized school administration. The internal inhibiting factors (weaknesses) consists of (a) the lack of participation of school members, (b) the utilization of facilities and infrastructure was not optimal, (c) limitations in the use of information technology.

Supporting and inhibiting factors are not only internal but also external. External supporting factors (opportunities) include (a) Educating the surrounding community, (b) Supporting Adipura, (c) Assistance from the government, (d) Supporting facilities and infrastructure, (e) Supporting the realization of Adiwiyata Village, (f) Good school accreditation, (g) Affecting other schools, and (h) becoming Adiwiyata reference school. Meanwhile, external inhibiting factors (threats) consisted of (a) lack of socialization, (b) disparities in lifestyles inside and outside school, (c) lack of resource persons and voluntary NGOs, (d) inadequate evaluation and supervision, and (e) change of school headmaster. The following are the results of the multiplication of weights and ratings in all aspects.

The supporting and inhibiting factors found in this study depend on the school and the local government's condition. Malang regency has a large enough area of 334,800 ha as the district with the second largest area in East Java Province after Surabaya Municipality (Utomo \& Satriawan, 2017). Representatives of the Environment Agency stated that the wide coverage area and limited personnel are the triggers for the emergence of inhibitory factors such as difficulty in socialization, supervision, and evaluation directly. The effectiveness of supervision is influenced by the number of personnel, infrastructure, and scope of supervised areas (Wahyuningsih et al., 2018). 
Adiwiyata (Green School) Program Optimization Strategy in Malang Regency to Realize Environmentally Friendly School Citizens

The financial condition of the school is also one of the obstacles because adiwiyata school is basically voluntary. The funding comes from the school's agreement to be willing to allocate a portion of the funds for the operation of the program. Existing funds are managed as well as possible to meet the needs. Financing-related obstacles are not only on the amount provided but also depend on human resources to be able to take advantage of existing money (Saputro, 2015).

Table. 2 Internal and external assessment scores.

\begin{tabular}{lcc}
\hline \multicolumn{1}{c}{ Strategic factors } & $\begin{array}{c}\text { Rewarded Adiwiyata } \\
\text { schools }\end{array}$ & Non-awarded Adiwiyata schools \\
\hline Strengths & 2,70 & 2,57 \\
Weakness & 0,35 & 0,34 \\
Opportunities & 3,18 & 0,99 \\
Threats & 0,30 & 1,07 \\
\hline
\end{tabular}

The score results uncovered that the strength and opportunities of the rewarded Adiwiyata schools were higher than the non-awarded Adiwiyata schools. This is by the identification results where adiwiyata award schools have advantages in infrastructure, administration, experience, and achievements. Adiwiyata School is awarded as a referral school that provides coaching and monitoring to adiwiyata schools not appreciated is still in the pioneering stage (Sulistyowati et al., 2017). The result of the score calculation is then used to determine the position point of SWOT Analysis. Determination of the SWOT matrix's position point employed the $\mathrm{x}$ and $\mathrm{y}$ axes, where the $x$-axis was the IFAS (reduction in the score of strengths with weaknesses), while the $y$-axis was EFAS (reduction in the score of opportunities and threats). The positions of the rewarded Adiwiyata schools and the non-awarded Adiwiyata schools are presented in the quadrant in the following figure.

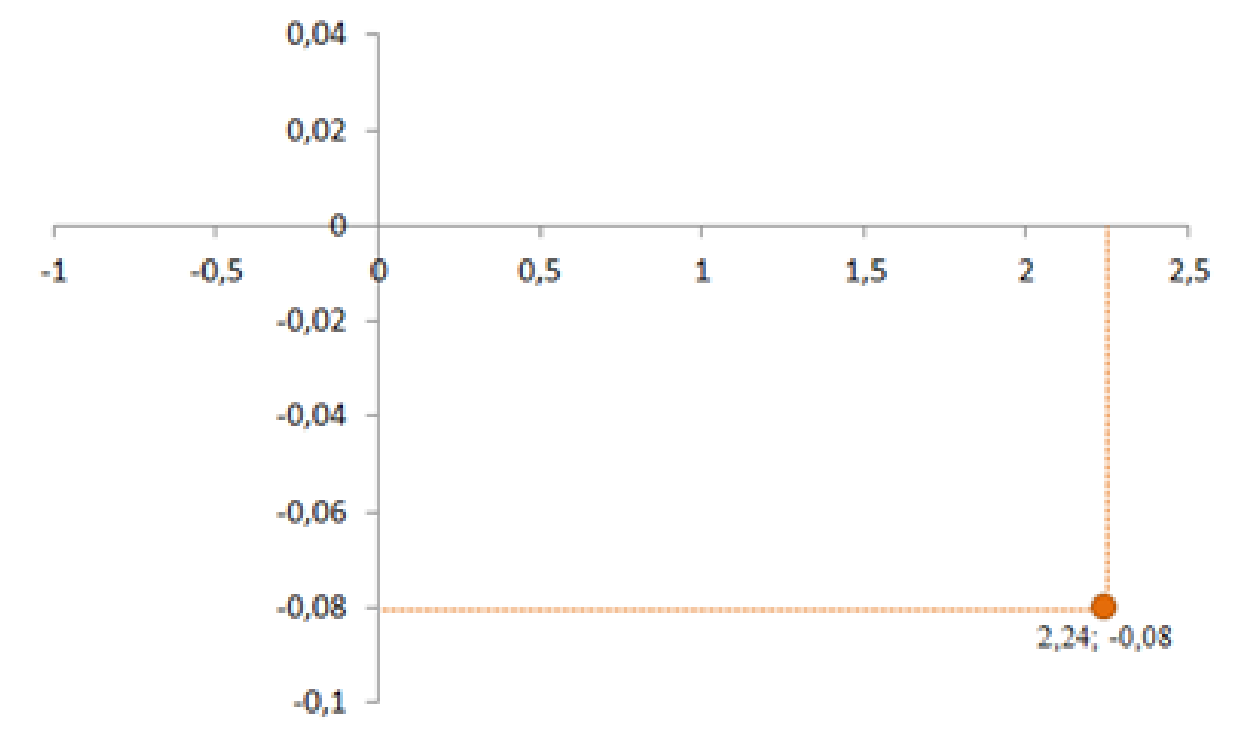

Figure 2. Position point of Non-Awarded Adiwiyata School. 
Adiwiyata (Green School) Program Optimization Strategy in Malang Regency to Realize Environmentally Friendly School Citizens

The picture above shows the Non-Award Adiwiyata School has a coordinate point of 2.24;-0.08 located in quadrant II. The position point in quadrant II indicates that the adiwiyata program faces various threats but still has internal strength. Non-award adiwiyata school is an impact school that needs guidance to foster enthusiasm, motivation, and commitment to actively participate in running the program (Sulistyowati et al., 2017).

Non-Award Adiwiyata School needs to formulate a strategy to stay afloat and not stop at this stage only. Competing strategies are utilized to maximize strength and opportunity in the face of threats (Riswandi et al., 2016). Internal strengths are used to take advantage of long-term opportunities through diversification strategies by developing new plans to support program development (Cahyono, 2016).

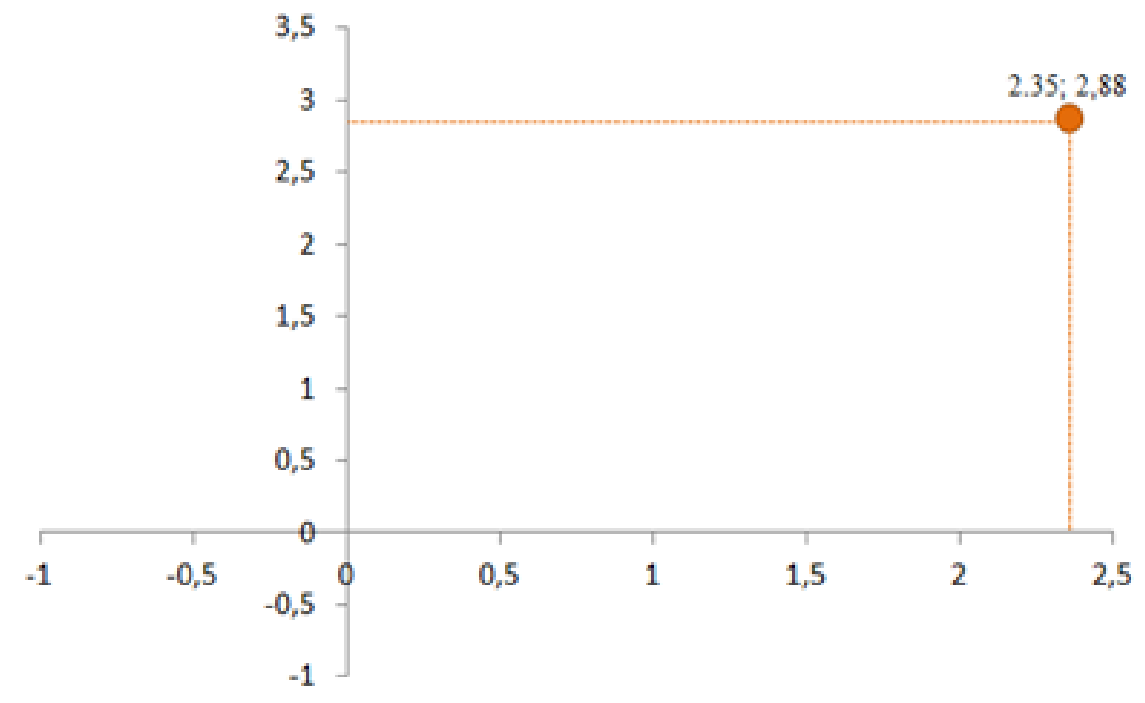

Figure 3. Position point of Rewarded Adiwiyata School.

In contrast to The Awarded Adiwiyata School's position, which has a coordinate point of 2,35;2.88 located in quadrant I. The position point in the quadrant I indicate that this program has great strength and opportunity to keep running (Awar \& Utami, 2012). Adiwiyata School has more complete facilities and infrastructure to support the program's success and has several extracurricular activities that bring many achievements and economic value. (Nuzulia et al., 2019).

Adiwiyata program is favorable because it has strengths and opportunities that can be utilized to the maximum to overcome weaknesses and face threats. In this situation, the strategy that needs to be formulated is to support the program to grow aggressively (Cahyono, 2016). An aggressive strategy is needed to support school quality growth by making strategic plans using internal forces to maximize external opportunities (Sujoko, 2017).

\section{Adiwiyata program optimization strategy SWOT analysis}

Based on the IFE and EFE matrix analysis results, a SWOT matrix could be prepared with four types of strategies: S-O, W-O, S-T, and W-T.

The SWOT analysis results at the non-awarded Adiwiyata school 
Adiwiyata (Green School) Program Optimization Strategy in Malang Regency to Realize Environmentally Friendly School Citizens

The Strength-Opportunity (SO) strategy includes (a) Carrying out regular environmental activities with local residents under the guidance of the local government to increase discipline and awareness in realizing Adiwiyata village (S.2, 4, 5 - O. 1, 3, 5); (b) Developing learning outside the classroom by making maximum use of facilities and infrastructure as well as mentoring (S. 3, 6- O. 3, 4); (c) Empowering Adiwiyata cadres and graduates to disseminate information and knowledge related to the PBLHS Movement and Adiwiyata to other schools to increase Malang Regency's chances of achieving Adipura (S. 1, 2, 6 - O. 2); (d) Making use of well-organized school administration to facilitate the school accreditation process and obtain good results because Adiwiyata conforms to eight educational standards (S. 7 - O. 6).

The Weakness-Opportunity Strategy (W-O) comprises (a) Involving school members in activities outside of school to increase participation and motivation in environmental conservation (W. 1 - O. 1); (b) Maximizing assistance from the local government to gain as much knowledge as possible to increase the ability of school members to use information technology and use of infrastructure (W. 2 - O. 3); (c) Studying and finding out the benefits of existing facilities and infrastructure and distributing excess facilities and infrastructure to the surrounding community so that they can be maximally utilized (W. 3 - O. 1, 4).

The Strength-Threat Strategy (S-T) consists of (a) Studying the Ministerial Regulations GPBLHS and Adiwiyata and making them a guide so that knowledge related to program planning and implementation is better (internalization of the Adiwiyata program to school residents) (S. 1 - T. 1); (b) Involving student guardians and enforcing other policies related to the Adiwiyata program to implement discipline and environmentally conscious behavior outside of school/home (S. 1, 4, 5, 6 - T. 2); (c) Empowering Adiwiyata cadres and graduates to overcome the lack of resource persons (S. 2, 6 - T. 3); (d) Enforcement of Ministerial Regulations GBPLHS and Adiwiyata to tighten monitoring and evaluation so that the Adiwiyata program is sustainable (S. 1 - T. 4); (e) There is a rule that prospective school headmaster must receive training or be certified as Adiwiyata cadres to have a high sense of environmental awareness (S. 1 - T. 5). The Weakness-Threats Strategy (W-T) contains making maximum use of technology and information and disseminating environmental conservation benefits to increase public knowledge and participation (W. 1, 3 - T. 1).

\section{The SWOT analysis results at the rewarded Adiwiyata schools}

The Strength-Opportunity (SO) strategy includes (a) Conducting environmental activities regularly with local residents under the guidance of the local government to increase discipline and awareness in realizing Adiwiyata Village (S.2, 4, 5 - O. 1, 4, 7); (b) Developing learning outside the classroom by making maximum use of facilities and infrastructure and mentoring (S. 3, 6 - O. 4, 5); (c) Empowering Adiwiyata cadres and graduates to disseminate information and knowledge related to the Movement of PBLHS and Adiwiyata to other schools to increase Malang Regency's chances of achieving Adipura (S. 1, 2, 6 - O. 2, 3); (d) Making use of well-organized school administration to facilitate the school accreditation process and obtain good results because Adiwiyata conforms to eight educational standards (S. 7 - O. 8); (e) Utilizing the advantages obtained to set an example and motivate reference schools to achieve better things (S. 4, 5, 6, 7 - O. 3, 6). 
Adiwiyata (Green School) Program Optimization Strategy in Malang Regency to Realize Environmentally Friendly School Citizens

The Weakness-Opportunity Strategy (W-O) consists of (a) Involving all school members in community or school impact education activities to increase participation and motivate school residents (W. 1 - O. 1, 6); (b) Maximizing assistance from the local government to gain as much knowledge as possible to improve the ability of school members to use information technology and the use of infrastructure (W. 2 - O. 4); (c) Studying and finding out the benefits of existing facilities and infrastructure and distributing excess facilities and infrastructure to the surrounding community or impacted schools so that they can be maximally utilized (W. 3 - O. 1, 3, 5).

The Strength-Threat (ST) strategy contains (a) Involving student guardians and enforcing other policies related to the Adiwiyata program to implement discipline and environmentally conscious behavior outside of school/home (S. 1, 4, 5, 6 - T. 1); (b) Enforcement of Ministerial Regulations GBPLHS and Adiwiyata to tighten monitoring and evaluation so that the Adiwiyata program is sustainable (S. 1 - T. 2); (c) There is a rule that prospective school headmaster must receive training or be certified as Adiwiyata cadres to have a high sense of environmental awareness (S. 1 - T. 3).

The Weakness-Threats Strategy (W-T) encompasses making maximum use of technology and information and disseminating environmental conservation benefits to increase public knowledge and participation (W. 1, 3 - T. 1).

\section{QSPM analysis}

The strategy needed to optimize the rewarded Adiwiyata schools was different from non-award schools. This is because the position points are in different quadrants, so it requires different strategies. Each category has two alternative strategies based on SWOT analysis performed. The non-award Adiwiyata School had an alternative growth and planning strategy. Meanwhile, the rewarded Adiwiyata schools has alternative development and sustainability strategies. To decide which strategy decisions to take or do first using QSPM analysis.

\section{The QSPM analysis results at the non-awarded Adiwiyata school}

SWOT analysis results show several alternative strategies. The table below show the QSPM analysis which was made to determine a strategy at non-awarded Adiwiyata school.

Table 3. QSPM Matrix of non-awarded Adiwiyata School.

\begin{tabular}{|c|c|c|c|c|c|}
\hline \multirow[t]{2}{*}{ Key Factors } & \multicolumn{3}{|c|}{$\begin{array}{l}\text { Strategy } 1 \\
\text { (Plan) }\end{array}$} & \multicolumn{2}{|c|}{$\begin{array}{l}\text { Strategy } 2 \\
\text { (Growth) }\end{array}$} \\
\hline & Weight & AS & TAS & AS & TAS \\
\hline \multicolumn{6}{|l|}{ Strengths } \\
\hline $\begin{array}{l}\text { 1. The existence of Ministerial Regulations for } \\
\text { GPBLHS and Adiwiyata, }\end{array}$ & 0,10 & 4 & 0,4 & 4 & 0,4 \\
\hline 2. The existence of the Adiwiyata team & 0,10 & 4 & 0,4 & 4 & 0,4 \\
\hline 3. Environmental atmosphere & 0,10 & 3 & 0,3 & 3 & 0,3 \\
\hline $\begin{array}{l}\text { 4. The school community was accustomed to } \\
\text { discipline }\end{array}$ & 0,09 & 3 & 0,27 & 3 & 0,27 \\
\hline $\begin{array}{l}\text { 5. The awareness of the school community } \\
\text { increased }\end{array}$ & 0,11 & 3 & 0,33 & 2 & 0,22 \\
\hline 6. Quality graduates and school members & 0,10 & 2 & 0,2 & 2 & 0,2 \\
\hline 7. Organized school administration & 0,12 & 3 & 0,36 & 3 & 0,36 \\
\hline
\end{tabular}


Adiwiyata (Green School) Program Optimization Strategy in Malang Regency to Realize Environmentally Friendly School Citizens

\begin{tabular}{|c|c|c|c|c|c|}
\hline \multicolumn{6}{|l|}{ Weakness } \\
\hline 1. The lack of participation of school members & 0,10 & 4 & 0,4 & 3 & 0,3 \\
\hline $\begin{array}{l}\text { 2. The utilization of facilities and infrastructure was } \\
\text { not optimal }\end{array}$ & 0,08 & 2 & 0,16 & 2 & 0,16 \\
\hline 3. Limitations in the use of information technology & 0,09 & 3 & 0,27 & 2 & 0,18 \\
\hline Total & 1,00 & & & & \\
\hline \multicolumn{6}{|l|}{ Opportunities } \\
\hline 1. Educating the surrounding community & 0,10 & 3 & 0,3 & 3 & 0,3 \\
\hline 2. Supporting Adipura & 0,07 & 2 & 0,14 & 2 & 0,14 \\
\hline 3. Assistance from the government & 0,10 & 4 & 0,4 & 3 & 0,3 \\
\hline 4. Supporting facilities and infrastructure & 0,10 & 4 & 0,4 & 3 & 0,3 \\
\hline 5. Supporting the realization of Adiwiyata Village & 0,06 & 2 & 0,12 & 3 & 0,18 \\
\hline 6. Good school accreditation & 0,10 & 3 & 0,3 & 3 & 0,3 \\
\hline \multicolumn{6}{|l|}{ Threats } \\
\hline 1. Lack of socialization & 0,10 & 4 & 0,4 & 3 & 0,3 \\
\hline 2. Disparities in lifestyles inside and outside school & 0,08 & 3 & 0,24 & 3 & 0,24 \\
\hline 3. Lack of resource persons and voluntary NGOs & 0,11 & 4 & 0,44 & 3 & 0,33 \\
\hline 4. Inadequate evaluation and supervision & 0,10 & 3 & 0,3 & 3 & 0,3 \\
\hline 5. Change of school headmaster & 0,10 & 4 & 0,4 & 4 & 0,4 \\
\hline Total & 1,00 & & 6,53 & & 5,88 \\
\hline
\end{tabular}

SWOT analysis position point is in quadrant II with the necessary strategy is to maximize strength and make the most of opportunities. Diversionary strategies are used to bring up new plans and ideas in program development (Cahyono, 2016). The QSPM score shows two strategies formulated with a higher planning strategy score than the growth strategy. That is, the planning strategy is carried out first and then maximized with the growth strategy. Preparation of strategies as follows.

\section{Planning Strategy}

Formulation of planning strategies at district/provincial Adiwiyata schools that can be implemented are (1) strengthening the Adiwiyata school team by fostering good cooperation and providing training in the use of information technology media to improve human resources; (2) creating a detailed and structured PBLHS Movement design; (3) making maximum use of assistance from the local government (Environmental Agency or Education Office) in preparing school administration; (4) internalization of the Adiwiyata program to all school members.

The district or provincial Adiwiyata school was in the early stages of joining the Adiwiyata program. A careful planning strategy is needed to determine the direction and objectives (Haythem, 2015). Adiwiyata School planning stages, as stated in the planning of the PBLHS Movement, must be detailed and precise. Adiwiyata School begins planning by including environmental management in the school's vision and mission. The formulation of a vision and mission is the first step used as a guide to achieving goals (Taiwo, Lawal, and Agwu, 2016).

\section{Growth Strategy}

Formulation of the growth strategy at the district/provincial Adiwiyata school can be done by (1) increasing the commitment of the school community and the Adiwiyata team to continue implementing environmentally sound behavior; (2) involving parents' role to participate in implementing environmentally sound behavior at home; (4) 
Adiwiyata (Green School) Program Optimization Strategy in Malang Regency to Realize Environmentally Friendly School Citizens

enriching learning methods by utilizing infrastructure as learning media; (d) using of social media, such as Instagram, Facebook, YouTube, and websites to disseminate environmental preservation.

The planning that has been made will run well if accompanied by an efficient movement to achieve the target (Rusniati, 2014). The Adiwiyata program is expected to become a long-term program so that it does not stop at the district or provincial level but can go to higher levels. A long-term orientation is manifested by a strategy that encourages the program to continue to grow, not only running today but also in the future (Ismoyo, 2013). Therefore, there needs to be a strategy that encourages the Adiwiyata program to grow well.

\section{The QSPM analysis results at the rewarded Adiwiyata school}

Same as non-awarded Adiwiyata school, the table below show the QSPM analysis which was made to determine a strategy at rewarded Adiwiyata school.

Table 4. QSPM Matrix of rewarded Adiwiyata School

\begin{tabular}{|c|c|c|c|c|c|}
\hline \multirow[t]{2}{*}{ Key Factors } & \multicolumn{3}{|c|}{$\begin{array}{c}\text { Strategy } 1 \\
\text { (Development) }\end{array}$} & \multicolumn{2}{|c|}{$\begin{array}{c}\text { Strategy } 2 \\
\text { (Sustainability) }\end{array}$} \\
\hline & Weight & AS & TAS & AS & TAS \\
\hline \multicolumn{6}{|l|}{ Strengths } \\
\hline $\begin{array}{l}\text { 1. The existence of Ministerial Regulations for } \\
\text { GPBLHS and Adiwiyata, }\end{array}$ & 0,1 & 2 & 0,2 & 2 & 0,2 \\
\hline 2. The existence of the Adiwiyata team & 0,1 & 4 & 0,4 & 3 & 0,3 \\
\hline 3. Environmental atmosphere & 0,1 & 4 & 0,4 & 3 & 0,3 \\
\hline $\begin{array}{l}\text { 4. The school community was accustomed to } \\
\text { discipline }\end{array}$ & 0,1 & 3 & 0,3 & 4 & 0,4 \\
\hline $\begin{array}{l}\text { 5. The awareness of the school community } \\
\text { increased }\end{array}$ & 0,1 & 2 & 0,2 & 3 & 0,3 \\
\hline 6. Quality graduates and school members & 0,1 & 3 & 0,3 & 3 & 0,3 \\
\hline 7. Organized school administration & 0,11 & 2 & 0,22 & 2 & 0,22 \\
\hline \multicolumn{6}{|l|}{ Weakness } \\
\hline 1. The lack of participation of school members & 0,11 & 2 & 0,22 & 1 & 0,11 \\
\hline $\begin{array}{l}\text { 2. The utilization of facilities and infrastructure } \\
\text { was not optimal }\end{array}$ & 0,06 & 2 & 0,12 & 2 & 0,12 \\
\hline $\begin{array}{l}\text { 3. Limitations in the use of information } \\
\text { technology }\end{array}$ & 0,09 & 1 & 0,09 & 1 & 0,09 \\
\hline Total & 1 & & & & \\
\hline \multicolumn{6}{|l|}{ Opportunities } \\
\hline 1. Educating the surrounding community & 0,11 & 4 & 0,44 & 3 & 0,33 \\
\hline 2. Supporting Adipura & 0,12 & 3 & 0,36 & 4 & 0,48 \\
\hline 3. Affecting other schools & 0,1 & 4 & 0,4 & 2 & 0,2 \\
\hline 4. Assistance from the government & 0,13 & 3 & 0,39 & 3 & 0,39 \\
\hline 5. Supporting facilities and infrastructure & 0,1 & 3 & 0,3 & 2 & 0,2 \\
\hline 6. Becoming Adiwiyata reference school & 0,11 & 3 & 0,33 & 4 & 0,44 \\
\hline 7. Supporting the realization of Adiwiyata Village & 0,12 & 4 & 0,48 & 3 & 0,36 \\
\hline 8. Good school accreditation & 0,11 & 3 & 0,33 & 3 & 0,33 \\
\hline \multicolumn{6}{|l|}{ Threats } \\
\hline $\begin{array}{l}\text { 1. Disparities in lifestyles inside and outside } \\
\text { school }\end{array}$ & 0,06 & 3 & 0,18 & 4 & 0,24 \\
\hline 2. Inadequate evaluation and supervision & 0,05 & 3 & 0,15 & 4 & 0,2 \\
\hline 3. Change of school headmaster & 0,1 & 4 & 0,4 & 4 & 0,4 \\
\hline Total & 1 & & 6,21 & & 5,91 \\
\hline
\end{tabular}


Adiwiyata (Green School) Program Optimization Strategy in Malang Regency to Realize Environmentally Friendly School Citizens

Furthermore, SWOT analysis position point is in quadrant 1, with the necessary strategy is to support the Adiwiyata program to grow aggressively. The strategic plan is formulated by utilizing internal forces to the maximum so that existing opportunities can be used properly (Sujoko, 2017). The QSPM score shows two strategies formulated with a higher development strategy score than the sustainability strategy. That is, the development strategy is carried out first and then continued with the sustainability strategy. Preparation of strategies as follows.

\section{Development Strategy}

Formulation of development strategies that can be carried out by the Nasional or Independent Adiwiyata schools such as; (1) developing the Adiwiyata Village program to increase the participation of the surrounding community; (2) maximizing the empowerment of Adiwiyata cadres and alumni students to spread the Adiwiyata program to impact schools and communities; (3) developing learning innovations; (4) providing outreach and guidance to develop human resources for school residents regularly.

The Adiwiyata school has an obligation to become an Adiwiyata reference school that fosters impact schools to participate in the Adiwiyata program. The GPBLHS Ministerial Regulation states that the National Adiwiyata School will obtain an independent Adiwiyata title if it can coach at least two Regency Adiwiyata schools. A development strategy is needed to disseminate a program and establish cooperation between organizations (schools) (Nurhaeni et al., 2019).

\section{Sustainability Strategy}

Besides, the sustainability strategies that the rewarded Adiwiyata schools need to undertake are (1) creating innovative environmental activities as an attraction for school residents to continue to carry out environmental conservation and management; (2) conducting self-evaluation and regular monitoring so that problems and difficulties related to the program can be more quickly identified and resolved; (3) giving awards to school members (for example, the best class, the best canteens, or the best cleaners) to motivate them to continue to adopt environmentally sound behavior. Awarding was shown to positively and significantly affect performance and could motivate better performance (Fitri et al., 2013; Nugroho, 2015).

Sustainability is a continuation of the development process, where the development of human resources in terms of knowledge, attitudes, and skills has the aim of bringing about sustainable change in a person's life (Morgan, 2016). The Adiwiyata program is one form of environmental management implementation in the learning process to sustainable development (Desfandi, 2015). The main objective of the Adiwiyata program is to create school members who have a sense of responsibility for environmental management and preservation through good school governance to support sustainable development with participatory and sustainable main principles (Landriany, 2014).

Planning, growth, development, and sustainability strategies are strategies carried out by schools or internal strategies. Adiwiyata program is the embodiment of cooperation between the ministry of environment and the ministry of education and culture. Therefore there needs to be a strategy carried out by the relevant agency in optimizing the Adiwiyata program. Internal and external factors have the same 
Adiwiyata (Green School) Program Optimization Strategy in Malang Regency to Realize Environmentally Friendly School Citizens

important weight to be utilized effectively and efficiently in school development (Suliswiyadi, 2019). The external strategies that need to be carried out by the relevant agencies include:

* Enforce the Regulation of the Minister of Environment concerning pblhs and adiwiyata movements. The results of interviews and observations show that the Ministerial Regulation of GPBLHS has not been fully applied. Environmental law enforcement aims to regulate the community to accept and respond to sustainable development principles (Fadli et al., 2016). Mr. Tommy, as the representative of the Malang district environmental office, stated that the latest Regulations had not been implemented to the maximum due to the constraints of the covid-19 pandemic. Efficiency in monitoring and evaluation is usually done by meeting in one place, and this is due to the relatively large area of Malang Regency. The covid-19 pandemic caused obstacles in organizing the meeting. Socialization related to the Regulation of the Minister of GPBLHS and Adiwiyata needs to be widely disseminated as this Regulation is a guideline and direction for implementing the adiwiyata program from the center to the region (KNLH, 2012).

* Coping with the change of headmaster. A program's success depends on the leader's role as a driving force and decision-maker (Ismoyo, 2013). The change of school headmaster resulted in the sustainability of the Adiwiyata program. It is the main factor that threatens the Adiwiyata program's failure, indicated by the relatively high TAS value compared to other factors. Headmaster are expected to have qualifications regarding environmental management as a requirement to lead an Adiwiyata school. There is an appeal to continue the Adiwiyata program that has previously been running.

* Monitoring regularly and thoroughly. Adiwiyata program monitoring was still lacking. Some schools felt that the lack of supervision resulted in a lack of motivation and guidance from the related agencies. Less than optimal supervision will impact decreasing performance; conversely, if the supervision is good, it will increase motivation and performance (Septiawan and Mudasyir, 2018). It is hoped that supervision in the Adiwiyata program is the same as supervision on subjects. There are regular meetings every week or month so that supervision can be carried out profoundly and thoroughly.

\section{CONCLUSIONS}

Adiwiyata program is a program that aims to support environmental preservation and as a means of creating environmentally sound behavior. Adiwiyata schools in Malang Regency were still very few and encountered difficulties and obstacles in their implementation. The optimization strategies were formulated by identifying internal and external factors and then analyzed using SWOT and QSPM. Planning and growth strategies need to be applied to non-reward Adiwiyata schools (Regency/City and Province Adiwiyata). Meanwhile, development and sustainability strategies need to be carried out in the rewarded Adiwiyata schools (National Adiwiyata or Independent). These strategies are expected to make the Adiwiyata program more optimal in realizing environmentally friendly school residents. This formulated strategy is expected to make the adiwiyata program more optimal in realizing environmentally sound school residents. This strategy can then be used as a reference for schools in developing 
Adiwiyata (Green School) Program Optimization Strategy in Malang Regency to Realize Environmentally Friendly School Citizens

programs. This strategy can also be used as a reference for the government in developing programs in each Adiwiyata school. Research is limited to strategy formulation. There needs to be further research related to the implementation of strategies to measure effectiveness and efficiency.

\section{REFERENCES}

Aldi, B. E. (2015). Upaya generalisasi konsep manajemen strategik. Jurnal Ilmu Ekonomi $\mathcal{E}$ Sosial, 6(2), 56-72. DOI: https://doi.org/10.35724/jies.v6i2.503

Anwar, M. C., \& Utami, M. C. (2012). Analisis SWOT pada strategi bisnis dalam kompetisi pasar (studi kasus: toko pojok madura). Studia Informatika: Jurnal Sistem Informasi, 5(1). DOI: https://doi.org/10.15408/sijsi.v5i1.282

Bandiyah, B. (2016). Pelatihan dan pendampingan penyusunan RPJM desa berbasis partisipatif di desa Lokasari, Sidemen, Karangasem, Bali. Jurnal Pengabdian Pada Masyarakat, 1(1), 11-17. https:// doi.org/10.30653/002.201611.3

Banihashemi, S. A., \& Rejaei, Z. (2016). Assessment of environmental conditions and internal capabilities affecting university strategies (IFE, EFE, SWOT \& AHP Models). International Journal of Asian Social Science, 6(10), 558-567. DOI: http://10.18488/journal.1/2016.6.10/1.10.558.567

Bradshaw, C., Atkinson, S., \& Doody, O. (2017). Employing a qualitative description approach in health care research. Global Qualitative Nursing Research, 4. DOI: https://doi.org/ 10.1177/2333393617742282

Cahyono, P. (2016). Implementasi strategi pemasaran dengan menggunakan metode swot dalam upaya meningkatkan penjualan produk jasa asuransi kecelakaan dan kematian pada PT. PRUDENTIAL cabang Lamongan. JPIM (Jurnal Penelitian Ilmu Manajemen), 1(2), 10-20. DOI: http://dx.doi.org/ 10.30736\%2Fjpim.v1i2.28

David, F. R., \& David, F. R. (2016). Manajemen strategik: Suatu pendekatan keunggulan bersaing. Jakarta: Salemba Empat.

Desfandi, M. (2015). Mewujudkan masyarakat berkarakter peduli lingkungan melalui program Adiwiyata. SOSIO-DIDAKTIKA: Social Science Education Journal, 2(1), 3137. DOI: https://doi.org/10.15408/sd.v2i1.1661

Ergashev, I., \& Farxodjonova, N. (2020). INTEGRATION OF NATIONAL CULTURE IN THE PROCESS OF GLOBALIZATION. Journal of Critical Reviews, 7(02), 477-479. DOI: https://doi.org/10.31838/jcr.07.02.90

Fadli, M., Mukhlish., \& Luthfi, M. (2016). Hukum dan kebijakan lingkungan (1 ${ }^{\text {st }}$ ed.). Malang: UB Press.

Fahmy, R., Bachtiar, N., Rahim, R., \& Malik, M. (2015). Measuring student perceptions to personal characters building in education: an indonesian case in implementing new curriculum in high school. Procedia - Social and Behavioral Sciences, 211, 851858. DOI: https:// doi.org/10.1016/j.sbspro.2015.11.112

Fitri, S. M., Ludigdo, U., \& Djamhuri, A. (2013). Pengaruh gaya kepemimpinan, komitmen, organisasi, kualitas sumber daya, reward, dan punishment terhadap anggaran berbasis kinerja (studi empirik pada pemerintah kabupaten LOMBOK barat). Jurnal Dinamika Akuntansi,5(2). DOI: https://doi.org/10.15294/ jda.v5i2.2996 
Adiwiyata (Green School) Program Optimization Strategy in Malang Regency to Realize Environmentally Friendly School Citizens

Haythem, A. (2015). The role of strategic planning in performance management. International Journal of Multi Disciplinary Research, 2(3), 2348-2052. http:// www.express-journal.com/

Hendryadi, H. (2017). Validitas isi: tahap awal pengembangan kuesioner. Jurnal Riset Manajemen dan Bisnis (JRMB) Fakultas Ekonomi UNIAT, 2(2), 169-178. DOI: https://doi.org/10.36226/jrmb.v2i2.47

Ismoyo, T. U. (2013). Kepemimpinan: Usaha pemberdayaan pemimpin baru menuju pertumbuhan organisasi berkelanjutan. Humaniora, 4(2), 811-821. DOI: https://doi.org/10.21512/humaniora.v4i2.3509

Isnaeni, Y. (2013). Implementasi kebijakan sekolah peduli dan berbudaya lingkungan di smp negeri 3 Gresik. Jurnal Kebijakan dan Pengembangan Pendidikan, 1(2). DOI: https://doi.org/10.22219/jkpp.v1i2.1565

Isnaeni, Y. (2014). Implementasi kebijakan program adiwiyata di SMP negeri 3 Gresik. Jurnal Kebijakan dan Pengembangan Pendidikan, 2(2). DOI: https://doi.org/10. 22219/jkpp.v2i2.1911

Iswari, R. D., \& Utomo, S. W. (2017). Evaluasi penerapan program adiwiyata untuk membentuk perilaku peduli lingkungan di kalangan siswa (kasus: SMA Negeri 9 Tangerang Selatan dan MA Negeri 1 Serpong). Jurnal Ilmu Lingkungan, 15(1), 35. DOI: https:// doi.org/10.14710/jil.15.1.35-41

Kementerian Negara Lingkungan Hidup. (2012). Panduan adiwiyata. Jakarta: KNLH.

Landiany, Ellend. (2014). Implementasi kebijakan adiwiyata dalam upaya mewujudkan pendidikan lingkungan hidup di SMA kota Malang. Jurnal Kebijakan dan Pengembangan Pendidikan. 2(1), 82-88. DOI: https://doi.org/10. 22219/jkpp.v2i1.1739

Miles MB, Huberman A M, dan Saldana J. (2014). Qualitative data analysis, a methods sourcebook, edition 3. USA: Sage Publications. Terjemahan Tjetjep Rohindi Rohidi, UI-Press. Jakarta.

Morgan, J. (2016). Children and youth services review participation, empowerment and capacity building: Exploring young people's perspectives on the services provided to them by a grassroots NGO in sub-Saharan Africa. Children and Youth
Services
Review,
65 ,
175-182.
DOI:
http://doi.org/10.

1016/j.childyouth.2016.04.012

Nugrahani, F., \& Hum, M. (2014). Metode penelitian kualitatif. Solo: Cakra Books.

Nurhaeni, I. D. A., Nugroho, R. A., \& Kusumawati, N. S. (2019). Developing strategic plan for supporting internationalization of technical and vocational education and training. In 5th UPI International Conference on Technical and Vocational Education and Training (ICTVET 2018). Atlantis Press. DOI: https://dx.doi.org/ 10.2991/ictvet$\underline{18.2019 .74}$

Nuzulia, S., Sukamto, S., \& Purnomo, A. (2019). Implementasi program adiwiyata mandiri dalam menanamkan karakter peduli lingkungan. SOSIO DIDAKTIKA: Social Science Education Journal, 6(2), 155-164. DOI: https://doi.org/10.15408/sd.v6i2.11334

Pane, M. M., \& Patriana, R. (2016). The significance of environmental contents in character education for quality of life. Procedia - Social and Behavioral Sciences, 222, 244-252. https:// doi.org/10.1016/j.sbspro.2016.05.153 
Adiwiyata (Green School) Program Optimization Strategy in Malang Regency to Realize Environmentally Friendly School Citizens

Pazouki, M., Jozi, S., \& Ziari, Y. (2017). Strategic management in urban environment using SWOT and QSPM model. Global Journal of Environmental Science Management, 3(2), 207-216. DOI: https://doi.org/10.22034/gjesm.2017.03.02.009.

Pradini, I. K., Sudjanto, B., \& Nurjannah, N. (2018). Implementasi program sekolah adiwiyata dalam peningkatan mutu pendidikan di SDN Tanah Tinggi 3 Kota Tangerang. Jurnal Green Growth Dan Manajemen Lingkungan, 7(2), 122-132. DOI : https://doi.org/10.21009/jgg.072.03

Pramanik, R. A., Purnomo, E. P., \& Kasiwi, A. N. (2020). Dampak perizinan pembangunan PLTU batang bagi kemajuan perekonomian masyarakat serta pada kerusakan lingkungan. KINERJA, 17(2), 248-256. DOI: http://dx.doi.org/10. 29264/ jkin.v17i2.7422

Pratiwi, R. D., Rusdi, R., \& Komala, R. (2019). The effects of personality and intention to act toward responsible environmental behavior. Jurnal Pendidikan Biologi Indonesia, 5(1), 169-176. https://doi.org/10.22219/jpbi.v5i1.7120

Riswandi, A., Thahir, H., \& Santi, I. N. (2016). Analisis strategi bersaing rumah makan (studi pada rumah makan darisa café campus). Jurnal Ilmu Manajemen Universitas Tadulako, 2(3), 293-304. DOI: https://doi.org/10.22487/jimut.v2i3.66

Rokhman, F., Hum, M., Syaifudin, A., \& Yuliati. (2014). Character education for golden generation 2045 (national character building for indonesian golden Years). Procedia - Social and Behavioral Sciences, 141, 1161-1165. DOI: https://doi.org/10. 1016/j.sbspro. 2014.05.197

Rusniati, H. A. (2014). Perencanaan strategis dalam perspektif organisasi. Jurnal Intekna, 16(2), 202-209.

Saputro, R. (2015). Implementasi program adiwiyata dalam pengelolaan lingkungan sekolah di SMA Negeri 1 Jekulo Kudus. Edu Geography, 3(6).

Septiawan, B., \& Mudasyir, A. (2018). Analisis pengaruh motivasi dan pengawasan terhadap peningkatan kinerja karyawan di cv. Bahrul maghfiroh kota malang. Akuntabilitas: Jurnal Ilmiah Ilmu-Ilmu Ekonomi,11(1), 58-66. DOI: https:// doi.org/10.35457/akuntabilitas.v11i1.466

Setyanto, R.P., (2018). Perilaku konsumsi sadar ekologis: pendekatan pemodelan multipe indicator multiple causes. Jurnal Ekonomi, Bisnis, dan Akuntansi, 20(1), 1-4.

Sujoko, E. (2017). Strategi peningkatan mutu sekolah berdasarkan analisis SWOT di sekolah menengah pertama. Kelola: Jurnal Manajemen Pendidikan, 4(1), 83-96. DOI: https://doi.org/10.24246/j.jk.2017.v4.i1.p83-96

Sulistyowati, R., Slameto, S., \& Dwikurnaningsih, Y. (2017). Pengembangan model pembinaan sekolah imbas adiwiyata berbasis partisipasi. Kelola: Jurnal Manajemen Pendidikan, 4(1), 97-108. DOI: https://doi.org/10.24246/j.jk.2017.v4.i1.p97-108

Suliswiyadi. (2019). Analisis SWOT Strategi Pengembangan Sekolah Unggul: Studi Kasus SD Islam Al Firdaus Kabupaten Magelang. Jurnal Tarbiyatuna, 10(1), 21-31. DOI: https://doi.org/10.31603/tarbiyatuna.v10i1.2709

Taiwo A.A, Lawal F.A and Agwu M.E. (2014). Vision and mission in organization: Myth or heuristic device?. The International Journal of Bussiness and Management, 4(3), 127-134. https:// ssrn.com/abstract=3122445

Tompodung, T. C. G., Rushayati, S. B., \& Aidi, M. N. (2018). Efektivitas program adiwiyata terhadap perilaku ramah lingkungan warga sekolah di kota 
Adiwiyata (Green School) Program Optimization Strategy in Malang Regency to Realize Environmentally Friendly School Citizens

depok. Journal of Natural Resources and Environmental Management, 8(2), 170-177. DOI: https:// doi.org/10.29244/jpsl.8.2.170-177

Utomo, S. J., \& Satriawan, B. (2017). Strategi Pengembangan desa wisata di kecamatan karangploso kabupaten Malang. Jurnal Neo-Bis, 11(2), 142-153. DOI: https://doi.org/10.21107/nbs.v11i2.3381

Wahyuningsih, S. M., Anggoro, S., \& Hartoko, A. (2019). Analisis evaluasi pengawasan zona di kawasan konservasi pulau menjangan, bali. Jurnal Pengelolaan Sumberdaya Alam dan Lingkungan (Journal of Natural Resources and Environmental Management), 9(2), 264-275. DOI: https://10.29244 /jps1.9.2.264-275

Yogi, P., Rizal, O., Ahmadi, S., \& Suharyo, O, S. (2017). Feasibility analysis of naval base relocation using SWOT and AHP method to support main duties operation. Journal of Defense Management, 7(1), 1-8. DOI: https://doi.org/ $\underline{10.4172 / 2167-0374.1000160}$

\section{*Hana Naqiyya Nada (Corresponding Author)}

Postgraduate School, Department of Environmental Science,

Universitas Sebelas Maret,

Jl. Ir. Sutami No. 36A, Pucangsawit, Jebres, Surakarta City, Central Java 57126 Indonesia

Email: hananaqiyya.22@gmail.com

\section{Rhina Uchyani Fajarningsih}

Postgraduate School, Department of Environmental Science,

Universitas Sebelas Maret,

J1. Ir. Sutami No. 36A, Pucangsawit, Jebres, Surakarta City, Central Java 57126 Indonesia

Email: rhinauchyani@staff.uns.ac.id

\section{Okid Parama Astirin}

Postgraduate School, Department of Environmental Science,

Universitas Sebelas Maret,

Jl. Ir. Sutami No. 36A, Pucangsawit, Jebres, Surakarta City, Central Java 57126 Indonesia

Email: okidparama@gmail.com 